\title{
In vitro and in vivo inhibition of Daphnia magna acetylcholinesterase by surfactant agents: possible implications for contamination biomonitoring
}

\author{
L. Guilhermino ${ }^{\mathrm{a}, *}$, M.N. Lacerda ${ }^{\mathrm{a}}$, A.J.A. Nogueira ${ }^{\mathrm{b}}$, A.M.V.M. Soares ${ }^{\mathrm{b}}$ \\ ${ }^{a}$ Instituto de Ciências Biomédicas de Abel Salazar, Departamento de Estudos de Populações, Laboratório de Ecotoxicologia, \\ Centro de Innes, Tigaçáo Marinhae Ambiental, Universidade do Porto, Lg. Prof. Abel Salazar, 2, 4099-003 Porto, Portugal \\ ${ }^{\mathrm{b}}$ Instituto do Ambiente e Vida / Departmento de Zoologia, Universidade de Coimbra, Lg. Marquês de Pombal, \\ 3000 Coimbra, Portugal
}

\begin{abstract}
This study was designed to investigate the effect of two surfactants, dodecyl benzyl sulfonate (DBS), sodium dodecyl sulfate (SDS), and of a domestic detergent (Y) on the AChE activity of the crustacean cladoceran Daphnia magna. All the chemicals significantly inhibit the activity of the enzyme, both in vitro and in vivo conditions. In vitro lowest observed effect concentration (LOEC) values ranged from 12.5 to $100 \mathrm{mg} / 1$ and correspondent $\mathrm{IC}_{50}(50 \%$ inhibition concentration) values ranged from 6.6 to $58.5 \mathrm{mg} / \mathrm{l}$. In vivo LOEC values ranged from 2 to $11.9 \mathrm{mg} / \mathrm{l}$, while $\mathrm{EC}_{50}(50 \%$ effect concentration) values ranged from 11.4 to $56.7 \mathrm{mg} / \mathrm{l}$. AChE inhibition by environmental contaminants such as surfactants, detergents and metals may lead to false diagnostics and even wrong conclusions in biomonitoring studies based on the use of $\mathrm{AChE}$ as a specific biomarker for organophosphorous and carbamate compounds. (C) 2000 Elsevier Science B.V. All rights reserved.
\end{abstract}

Keywords: Biomarkers; Acetylcholinesterase; Daphnia magna; Surfactants

\section{Introduction}

Acetylcholinesterase (AChE) is the enzyme that hydrolyses the neurotransmitter acetylcholine in cholynergic synapses of both vertebrates and invertebrates. This enzyme is strongly inhibited by organophosphate and carbamate pesticides at low concentrations and, for this reason, has been

\footnotetext{
* Corresponding author. Tel.: +351-2-2062252; fax: +3512-2062232.

E-mail address: lguilher@ICBAS.up.pr (L. Guilhermino).
}

widely used as a specific biomarker for these compounds.

In the last decades, the inhibition of cholinesterases from several species by environmental contaminants other than organophosphate and carbamate pesticides has been increasingly reported. The group of metals was, probably, the first class of environmental pollutants that was found to include non-specific anti-cholinesterase agents. The potential of some metallic ions, such as $\mathrm{Hg}^{2+}, \mathrm{Cu}^{2+}, \mathrm{Zn}^{2+}, \mathrm{Cd}^{2+}$, and $\mathrm{Pb}^{2+}$ to depress the activity of cholinesterases of fish and inverte- 
brates, in vitro and/or in vivo conditions, has been demonstrated in several studies (Olson and Christensen, 1980; Gill et al., 1990, 1991; Schmidt and Ibrahim, 1994; Labrot et al., 1996). Recently, undetermined components of complex mixtures of pollutants were also found to inhibit $\mathrm{AChE}$ activity (Payne et al., 1996). Synthetic detergents are major pollutants of the aquatic environment. These compounds have both industrial and domestic uses and are released into natural waters in effluents. Modern detergents are biodegradable in water and are considered not to accumulate in the environment (Malcom et al., 1995). Nevertheless, due to a continuous input they may attain relatively high concentrations in some areas (WHO, 1996). Studies published in the last years report in vitro inhibitor effects of detergents and surfactants on the activity of cholinesterases of Mytilus galloprovincialis and Moina macropa (Martínez-Tabche et al., 1996; Guilhermino et al., 1998) at concentrations in the range of milligrams per litre.

Daphnia magna is a standard organism in ecotoxicology. It is relatively easy to maintain in the laboratory, has a short life cycle, requires low culture and test medium volumes and a great deal of information available about it exists. Furthermore, the inhibition of $D$. magna $\mathrm{AChE}$ is a suitable criterion to be used in toxicity tests (Guilhermino et al., 1996a). For these reasons, D. magna was chosen as the test organism in this study.

Here, we investigated the in vitro and in vivo effects of two surfactants, dodecyl benzyl sulfonate (DBS) and sodium dodecyl sulfate, and of a mixture commonly used as domestic detergent (Y) on the activity of the enzyme acetylcholinesterase of D. magna.

\section{Material and methods}

\subsection{Parental cultures}

Progenitors were cultured in groups of 10 per $800 \mathrm{ml}$ of the medium ASTM (American Society for Testing and Materials) hard water (ASTM, 1980) with an organic additive (Baird et al., 1989) and fed three times a week with $0.322 \mathrm{mg}$ of Carbon per daphnia per day. Photoperiod was 16:8 $\mathrm{h} \mathrm{L} / \mathrm{D}$ and temperature was $20 \pm 1^{\circ} \mathrm{C}$.

\subsection{Toxicity tests}

In vitro and in vivo $\mathrm{AChE}$ inhibition tests were performed according to Guilhermino et al. (1996a). Briefly, for in vitro tests, juveniles $(<24$ $h$ old) were isolated from parental cultures and maintained in groups of 20 per $800 \mathrm{ml}$ of ASTM during $48 \mathrm{~h}$ with no food. After this period, organisms were used to prepare homogenates which were incubated during $30 \mathrm{~min}$ with several concentrations of each toxicant $(0,12.5,25,50$ and $100 \mathrm{mg} / \mathrm{l})$. In vivo AChE inhibition tests were performed by exposing juveniles $(<24 \mathrm{~h}$ old $)$ to several concentrations of each test substance (DBS: 0, 2, 3, 4.5, 6.7 and $10 \mathrm{mg} / \mathrm{l}$; SDS and Y: 0, 7.9, 11.9, 17.8, 26.7 and $40 \mathrm{mg} / \mathrm{l})$ for $48 \mathrm{~h}$. After this period, live animals were used to prepare homogenates for AChE determinations.

\subsection{Homogenate preparation}

Homogenates were prepared in ice cold phosphate buffer (0.1 M, pH 7.2) using a homogeniser, according to the procedure described by Guilhermino et al. (1996b).

\subsection{AChE determination}

AChE activity in the homogenates was determined by the method of Ellman et al. (1961), adapted to microplate (Herbert et al., 1995) and optimised for D. magna (Guilhermino et al., 1996b). Acetylthiocholine was used as substrate in all the assays and no attempt was made to distinguish between $\mathrm{AChE}$ and pseudo-cholinesterase. The activity of the enzyme was expressed in units (U) per milligrams of protein, corresponding $1 \mathrm{U}$ to $1 \mathrm{nmol}$ of substrate hydrolysed per minute per millilitre. A Labsystems Multiskan MS microplate reader was used.

\subsection{Protein concentration}

Protein concentration in the samples was de- 
termined by the Bradford technique (Bradford, 1976) and adapted to microplate (Herbert et al., 1995).

\subsection{Toxicant solutions}

Solutions of DBS, SDS and Y were prepared immediately before the beginning of the tests in micro-pure water. For each test, daily prepared solutions were used. Data analysis was based on nominal concentrations.

\subsection{Chemicals}

Acetylthiocholine, 5,5'-dithio-bis $(\gamma$-nitrobenzoic acid) (DTNB) and $\gamma$-bovine globulins were purchased from SIGMA (USA), Bradford reagent was from BIO-RAD (UK). DBS ( $>98 \%$ pure) was a gift from UNILEVER (UK), SDS (99\% pure) was from MERCK (Germany). ' $\mathrm{Y}$ ' was a washing mixture for domestic use commonly found in the market.

\subsection{Data analysis}

Data were analysed by Analysis of Variance (ANOVA). No-observed effect concentration (NOEC) and lowest observed effect concentration
(LOEC) values were determined by Ducan multicomparison test. The concentration of inhibition at $50 \%\left(\mathrm{IC}_{50}\right)$ and the $50 \%$ effect concentration $\left(\mathrm{EC}_{50}\right)$ values were calculated by probit analysis (Finney, 1971). The significance level was 0.05 .

\section{Results}

All the compounds significantly inhibited the AChE activity of D. magna in vitro (DBS: $F=$ 31.6, $P<0.05$; SDS: $F=102.3, P<0.05$; Y: $F=$ 16.3, $P<0.05$ ) (Fig. 1). DBS was the more effective inhibitor $[\mathrm{NOEC}<12.5 \mathrm{mg} / \mathrm{l}, \mathrm{LOEC}=12.5$ $\mathrm{mg} / \mathrm{l}$ and $\mathrm{IC}_{50}=6.6 \mathrm{mg} / \mathrm{l} \quad(95 \% \quad \mathrm{CL}=6.1-7.2$ $\mathrm{mg} / \mathrm{l})]$ and $\mathrm{Y}$ was the least effective $[\mathrm{NOEC}=50$ $\mathrm{mg} / \mathrm{l}, \mathrm{LOEC}=100 \mathrm{mg} / \mathrm{l}$ and $\mathrm{IC}_{50}=58.8 \mathrm{mg} / \mathrm{l}$ $(95 \% \mathrm{CL}=52.1-65.5 \mathrm{mg} / \mathrm{l})]$. SDS showed an anti-cholinesterase intermediate effect $[\mathrm{NOEC}=$ $25 \mathrm{mg} / \mathrm{l}, \quad \mathrm{LOEC}=50 \mathrm{mg} / \mathrm{l}, \quad \mathrm{IC}_{50}=50.1 \mathrm{mg} / 1$ $(95 \% \mathrm{CL}=44.2-56.9 \mathrm{mg} / \mathrm{l})]$.

Daphnids exposed in vivo to DBS, SDS or Y showed lower levels of AChE than unexposed animals (Fig. 2). To each chemical, the differences among treatments are significant (DBS: $F$ $=18.7, P<0.05$; SDS: $F=13.5, P<0.05$; Y: $F=$ $39.2, P<0.05)$. DBS significantly depressed AChE activity at concentrations equal to, or higher than

\section{in vitro}

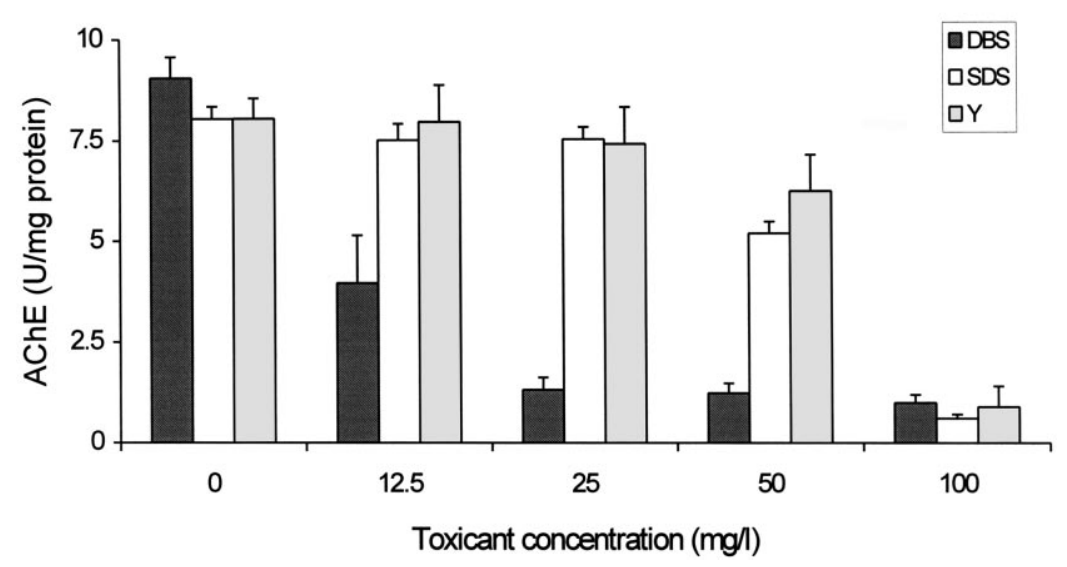

Fig. 1. In vitro effect of DBS, SDS and $\mathrm{Y}$ on AChE activity of D. magna. Values are the mean of three replicates with correspondent $95 \%$ error bars (S.E.M.). 


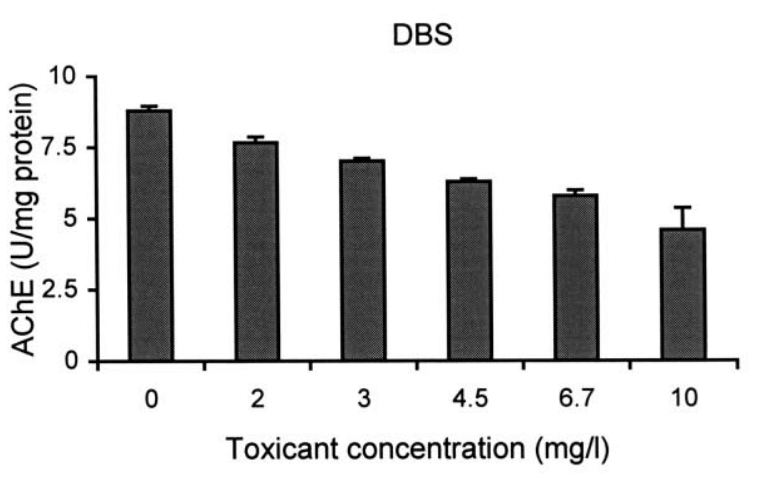

SDS
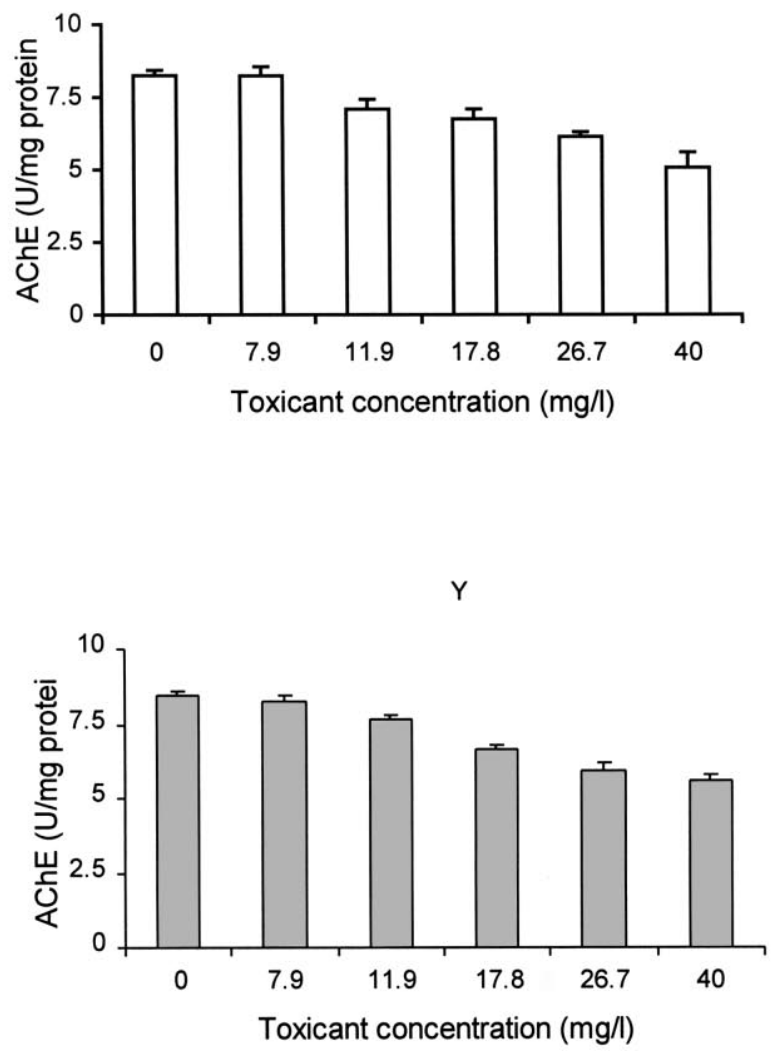

Fig. 2. In vivo effect of DBS, SDS and Y on AChE activity of D. magna. Values are the mean of three replicates with correspondent $95 \%$ error bars (S.E.M.).

$2 \mathrm{mg} / 1$ (NOEC $<2 \mathrm{mg} / \mathrm{l})$, SDS at concentrations equal to, or higher than $11.9 \mathrm{mg} / \mathrm{l}(\mathrm{NOEC}=7.9$ $\mathrm{mg} / \mathrm{l})$ and $\mathrm{Y}$ at concentrations equal to, or higher than $17.8 \mathrm{mg} / \mathrm{l}(\mathrm{NOEC}=11.9 \mathrm{mg} / \mathrm{l}) . \mathrm{EC}_{50}$ values were $11.4 \mathrm{mg} / \mathrm{l}(95 \% \mathrm{CL}=8.1-15.9 \mathrm{mg} / \mathrm{l})$ for DBS, $51.5 \mathrm{mg} / 1(95 \% \mathrm{CL}=50.6-52.3 \mathrm{mg} / \mathrm{l})$ for SDS and $56.7 \mathrm{mg} / 1(55.4-58.2 \mathrm{mg} / \mathrm{l})$ for Y.

\section{Discussion}

This study was designed to investigate the effect of DBS, SDS and Y on AChE activity of $D$. magna. All the tested chemicals significantly inhibited the activity of the enzyme, both in vitro and in vivo conditions. These results are in complete agreement with other studies reporting in vitro anti-cholinesterase effects of surfactants (Martínez-Tabche et al., 1996; Guilhermino et al., 1998).

In vitro $\mathrm{LOEC}(50$ and $100 \mathrm{mg} / \mathrm{l})$ and $\mathrm{IC}_{50}$ (51.5 and $56.7 \mathrm{mg} / \mathrm{l}$ ) values found in this study for SDS and Y are higher than the range of surfactant concentrations (individual chemical concentrations) reported in the literature as generally occurring in aquatic environments. However, an in vitro $\mathrm{LOEC}$ of $12.5 \mathrm{mg} / 1$ and an $\mathrm{IC}_{50}$ of 6.6 $\mathrm{mg} / \mathrm{l}$ were found for DBS. These values compare with surfactant concentrations measured in polluted surface waters (1-10 mg/l) (WHO, 1996). Furthermore, in vivo LOECs were $2 \mathrm{mg} / 1$ for DBS and $11.9 \mathrm{mg} / 1$ for SDS and $\mathrm{Y}$, while $\mathrm{EC}_{50}$ values for these compounds were 11.4, 51.5 and $56.7 \mathrm{mg} / \mathrm{l}$, respectively. Concentrations of linear alkylbenzene sulfonates (LAS) near $10 \mathrm{mg} / 1$ have been measured in effluents (WHO, 1996). Total amount of surfactants and detergents in these effluents was probably higher than the concentration determined for LAS alone.

$\mathrm{AChE}$ is considered a specific biomarker for organophosphate and carbamate pesticides, being commonly used to diagnose exposure of natural populations to these chemicals. However, studies published in the last decades and the present one indicate that acetylcholinesterase may also be inhibited by metals, undetermined compounds of complex mixtures of pollutants, surfactants and detergents (Olson and Christensen, 1980; Gill et al., 1990, 1991; Schmidt and Ibrahim, 1994; Labrot et al., 1996; Martínez-Tabche et al., 1996; Payne et al., 1996; Guilhermino et al., 1998). This non- 
specific inhibitory effect may lead to false diagnostics and even wrong conclusions in biomonitoring studies based on the use of AChE as a specific biomarker in strongly polluted areas. Facing these results, the use of this endpoint as a specific biomarker has been questioned and a more general use for it has been suggested (Labrot et al., 1996; Guilhermino et al., 1998). From our point of view, the use of $\mathrm{AChE}$ as a specific biomarker should be very careful and only performed in adequate conditions. For example, when the contamination of the study area is known to be due to pesticides or when the pollutant is unknown but a suitable program of chemical monitoring is also used.

\section{Acknowledgements}

This study was supported by Fundação para a Ciência e Tecnologia (Portugal), and EU Contract ERBIC 18/CT98/0264.

\section{References}

ASTM Standard practice for conducting acute toxicity tests with fishes. Macroinvertebrates and amphibians. (Unpublished Rep. E-729-90). American standards for testing and materials. Philadelphia, 1980.

Baird DJ, Soares AMVM, Girling A, Barber I, Bradley MC, Calow P. The long-term maintenance of Daphnia magna Straus for use in ecotoxicity tests: problems and prospects. In: Lokke H, Tyle H, Bro-Rasmussen F, editors. Proceedings First European Conference on Ecotoxicology. Lyngby, 1989:144-148.

Bradford M. A rapid and sensitive method for the quantification of microgram quantities of protein utilizing the principle of protein dyebinding. Anal Biochem 1976;72:248-254.

Ellman GL, Courtney D, Andres Jr V, Feathrstone RM. A new and rapid colorimetric determination of acetylcholinesterase activity. Biochem Pharmacol 1961;7:88-95.

Finney DJ. Probit analysis, 3rd ed. Cambridge: Cambridge University Press, 1971.
Gill TS, Tewari H, Pande J. Use of fish enzyme system to monitoring water quality: effects of mercury on tissue enzymes. Comp Biochem Physiol 1990;97C:287-292.

Gill TS, Tewari H, Pande J. In vivo and in vitro effects of cadmium on selected enzymes in different organs of the fish Barbus conchonius (rosy barb.) comp. Biochem Physiol 1991;100C:501-505.

Guilhermino L, Lopes MC, Carvalho AP, Soares AMVM. Inhibition of acetylcholinesterase activity as effect criterion in acute tests with juvenile Daphnia magna. Chemosphere 1996a;32:727-738.

Guilhermino L, Lopes MC, Carvalho AP, Soares AMVM. Acetylcholinesterase activity in juveniles of Daphnia magna Straus. Bull Environ Contam Toxicol 1996b;57:979-985.

Guilhermino L, Barros P, Silva MC, Soares AMVM. Should the use of inhibition of cholinesterases as a specific biomarker for organophosphate and carbamate insecticides be questioned? Biomarkers 1998;3:157-163.

Herbert A, Guilhermino L, da Silva de Assis HC, Hansen P-D. Acetylcholinesterase activity in aquatic organisms as pollution biomarker. Z Angew Zool 1995;3:1-15.

Labrot F, Ribera D, Saint Denis M, Narbonne JF. In vitro and in vivo studies of potential biomarkers of lead and uranium contamination: lipid peroxidation, acetylcholinesterase, catalase and glutathione peroxidase activities in three nonmammalian species. Biomarkers 1996;1:21-28.

Malcom MH, Howe PD, Dobson S. Toxicity of LAS to aquatic organisms. TEM 1995;2:20-24.

Martínez-Tabche L, Mora BR, Faz CG et al. Toxic effects of sodium dodecylbenzenesulfonate, lead, petroleum, and their mixtures on the activity of acetylcholinesterase of Moina macropa in vitro. Environ Toxicol Water Qual 1996;12: 211-215.

Olson DL, Christensen GM. Effects of water pollutants and other chemicals on fish acetylcholinesterase (in-vitro). Environ Res 1980;21:327-335.

Payne JF, Mathieu A, Melvin W, Fancey LL. Acetylcholinesterase, an old biomarker with a new future? Field trials in association with two urban rivers and a paper mill in Newfoundland. Mar Pollut Bull 1996;32:225-231.

Schmidt GH, Ibrahim NHM. Heavy metal content $\left(\mathrm{Hg}^{2+}\right.$, $\mathrm{Cd}^{2+}, \mathrm{Pb}^{2+}$ ) in various body parts: its impact on cholinesterase activity and binding glycoproteins in the grasshopper Aiolopus thalassimus adults. Ecotoxicol Environ Safety 1994;29:148-164.

WHO. Environmental health criteria 169: linear alkylbenzene sulfonates and related compounds. Geneve: World Health Organization, 1996. 